\title{
Thyroid Gland Spindle Cell Follicular Adenoma
}

National Cancer Institute

\section{Source}

National Cancer Institute. Thyroid Gland Spindle Cell Follicular Adenoma. NCI Thesaurus.

Code C155957.

A rare thyroid gland follicular adenoma composed predominantly of spindle cells. 